Masataka Yokoyama MD, ${ }^{*}$ Masahisa Hirakawa MD,* Hiroshi Goto MD†

\title{
Clonidine does not affect lidocaine seizure threshold in rats
}

We investigated the effect of clonidine on intravenous (iv) lidocaine-induced haemodynamic changes and convulsions in awake rats. Wistar rats (200-250 g) were divided into three groups of eight and were pretreated with iv clonidine or normal saline $15 \mathrm{~min}$ before lidocaine infusion. Group 1 received normal saline; Group 2, $1 \mu \mathrm{g} \cdot \mathrm{kg}^{-1}$ clonidine; and Group 3, 10 $\mu \mathrm{g} \cdot \mathrm{kg}^{-1}$ clonidine. After surgical preparation and recovery from anaesthesia, all groups received a continuous iv infusion of lidocaine $\left(15 \mathrm{mg} \cdot \mathrm{ml}^{-1}\right)$ at a rate of $4 \mathrm{mg} \cdot \mathrm{kg}^{-1} \cdot \mathrm{min}^{-1}$ until generalized convulsions occurred. Oxygenation was well maintained in all groups. Pretreatment with clonidine changed neither cumulative convulsant doses (Group 1: $41.8 \pm 2.2$, Group 2: $43.8 \pm 2.6$, Group 3: $42.3 \pm 2.0 \mathrm{mg} \cdot \mathrm{kg}^{-1}$, respectively) nor plasma concentrations of lidocaine at the onset of convulsions (Group 1: 10.5 \pm 0.3 , Group 2: $10.8 \pm 0.3$, Group 3: $10.6 \pm 0.3 \mu \mathrm{g} \cdot \mathrm{ml}^{-1}$, respectively). The mean arterial blood pressures in Groups 2 and 3 were decreased after clonidine pretreatment (Group 2: $93 \pm 1, P<0.01$, Group 3: $90 \pm$ $1 \%, P<0.01$, respectively) and they gradually increased during lidocaine infusion. The heart rates decreased afier clonidine pretreatment (Group 2: $94 \pm 2, P<0.05$, Group 3: $86 \pm 2 \%$, $P<0.01$, respectively) and the combination of clonidine and lidocaine potentiated the bradycardic effect of lidocaine at a subconvulsant dose. Our results indicate that clonidine has neither anticonvulsant nor proconvulsant effects on lidocaineinduced convulsions. However, the interactions of clonidine and lidocaine on blood pressure and heart rate should be investigated further.

\section{Key words}

ANAESTHETICS, LOCAL: lidocaine;

COMPLICATIONS: Seizures;

SYMPATHETIC NERVOUS SYSTEM: clonidine.

From the *Department of Anesthesiology and Resuscitology, Okayama University Medical School, 2-5-1-Shikata, Okayama City 700, Japan, and the †Department of Anesthesiology, The University of Kansas Medical Center, 3901 Rainbow Blvd., Kansas City, Kansas 66160-7415, USA.

Address correspondence to: Dr. Masataka Yokoyama, Department of Anesthesiology and Resuscitology, Okayama University Medical School, 2-5-1 Shikata, Okayama City 700, Japan.

Accepted for publication 10th August, 1993.
Nous avons recherché chez des rats éveillés l'effet de la clonidine sur les variations hémodynamiques et les convulsions induites par la lidocä̈ne. Des rats Wistar (200-250 gr) sont répartis en trois groupes de huit et sont prétraités avec de la clonidine iv ou une solution physiologique 15 minutes avant une perfusion de lidocaine. Le groupe 1 reçoit la solution physiologique, le groupe 2 reçoit $1 \mu \mathrm{g} \cdot \mathrm{kg}^{-1}$ de clonidine, le groupe $3,10 \mu \mathrm{g} \cdot \mathrm{kg}^{-1}$ de clonidine. Après la préparation chirurgicale et le réveil de l'anesthésie, tous les groupes reçoivent une perfusion $\dot{N}$ continue de lidocaïne $\left(15 \mathrm{mg} \cdot \mathrm{ml}^{-1}\right)$ à une vitesse de $4 \mathrm{mg} \cdot \mathrm{kg}^{-1} \cdot \mathrm{min}^{-1}$ jusquà l'obtention de convulsions généralisées. L'oxygénation est bien maintenue dans tous les groupes. Le prétraitement par la clonidine ne change ni la dose totale génératrice de convulsions (groupe $1: 41,8 \pm 2,2$; groupe 2: 43,8 \pm 2,3; groupe 3: $42,3 \pm 2 \mathrm{mg} \cdot \mathrm{kg}^{-1}$ ) ni les concentrations plasmatiques de lidocaïne déclenchant les convulsions (groupe 1: 10,5 $\pm 0,3$; groupe 2: 10,8 \pm 0,3; groupe 3: 10,6 $\left.\pm 0,3 \mu \mathrm{g} \cdot \mathrm{ml}^{-1}\right)$. La pression artérielle moyenne dans les groupes 2 et 3 diminue après le prétraitement à la clonidine (groupe 2: $93 \pm 1, P<0,05$; groupe 3: $90 \pm 1 \%, P<0,01$ ) et remonte progressivement pendant la perfusion de lidocaïne. La fréquence cardiaque ralentit après le prétraitement à la clonidine (groupe 2: $94 \pm 2, P<0,05$, groupe 3: $86 \pm 2 \%, P$ $<0,01)$ et la combinaison de clonidine et de lidocaine renforce l'effet bradycardi sont de la lidocaïne à une dose infraconvulsivante. Nos résultats indiquent que la clonidine n'a d'effet ni anticonvulsivant, ni proconvulsivant sur les convulsions induites par la lidocaïne. Cependant, les interactions de la clonidine et de la lidocaïne sur la pression sanguine et la fréquence cardiaque devraient être examinées ultérieurement.

Clonidine, an $\alpha_{2}$-adrenoceptor agonist, has been used widely in anaesthesia practice. Clonidine administered intrathecally or epidurally produces analgesia. ${ }^{1-4}$ Clonidine administered orally has been reported to provide perioperative sedation, ${ }^{5,6}$ to reduce anaesthetic requirements ${ }^{7,8}$ and to produce postoperative analgesia, ${ }^{6}$ and intravenous clonidine can produce postoperative analgesia. $^{9}$

More recently, there have been several studies in regard to clonidine added to local anaesthetics. ${ }^{10-12}$ Nishikawa et $a l .{ }^{10}$ reported that the addition of clonidine to lidocaine for epidural anaesthesia tended to increase the plasma 
lidocaine concentrations. On the other hand, there have been conflicting reports that the large doses of clonidine have an anticonvulsant or a proconvulsant effect, depending on the aetiology of convulsions in animals. ${ }^{13-17}$ However, it has not been determined whether clinical doses of clonidine affect lidocaine-induced toxicity and convulsions, and the interaction between clonidine and lidocaine has not been studied. We employed an awake rat model to determine whether pretreatment with clonidine affects lidocaine-induced haemodynamic changes and seizure threshold.

\section{Methods}

The study was approved by the institutional animal care and use committee. Animals were fasted overnight (water was supplied ad libitum), and the experiments were performed between 1:00 and 5:00 p.m.

Twenty-four male Wistar rats weighing 200-250 g were anaesthetized with halothane in oxygen during surgical preparation. One femoral artery was cannulated with a polyethylene catheter to monitor mean arterial blood pressure (MAP) and heart rate (HR) and for blood sampling, and a femoral vein was cannulated for the infusion of drugs. The proximal ends of these catheters were tunneled subcutaneously to the posterior cervical region, so that the animals could move freely. Before emergence from anaesthesia, the animals were placed in a plastic container to recover for two hours before the experiment.

The animals were assigned randomly into three groups of eight to receive pretreatment with either clonidine or normal saline $15 \mathrm{~min}$ before the lidocaine infusion. The control group (Group 1) received normal saline solution $\left(1 \mathrm{ml} \cdot \mathrm{kg}^{-1}\right)$; Group 2 received $1 \mu \mathrm{g} \cdot \mathrm{kg}^{-1}$ clonidine in normal saline solution, $1 \mathrm{ml} \cdot \mathrm{kg}^{-1}$; and Group 3 received $10 \mu \mathrm{g} \cdot \mathrm{kg}^{-1}$ clonidine in normal saline solution, 1 $\mathrm{ml} \cdot \mathrm{kg}^{-1}$, iv over $30 \mathrm{sec}$. Clonidine (clonidine hydrochloride, Sigma Chemical Company) was dissolved in normal saline solution to a concentration of $1 \mu \mathrm{g} \cdot \mathrm{ml}^{-1}$ for Group 2 or $10 \mu \mathrm{g} \cdot \mathrm{ml}^{-1}$ for Group 3. After pretreatment, animals in all groups received a continuous intravenous infusion of lidocaine $\left(15 \mathrm{mg} \cdot \mathrm{ml}^{-1}\right)$ at a rate of 4 $\mathrm{mg} \cdot \mathrm{kg}^{-1} \cdot \mathrm{min}^{-1}\left(0.053-0.067 \mathrm{ml} \cdot \mathrm{min}^{-1}\right)$ by infusion pump (Harvard Microliter Syringe Pump) until generalized convulsions occurred. Total lidocaine doses from the beginning of the infusion to the onset of convulsions were calculated for each animal as Infusion rate $X$ infusion time.

Arterial blood pressure and HR were monitored and recorded continuously, and the animals were continuously observed for generalized convulsions.

Arterial blood, $0.2 \mathrm{ml}$, was drawn just before beginning the lidocaine infusion and $1.0 \mathrm{ml}$ at the onset of convulsions to determine blood gas tensions, $\mathrm{pH}$, and plasma concentrations of lidocaine. For determination of plasma concentrations of lidocaine, blood samples were centrifuged and the plasma was frozen at $-80^{\circ} \mathrm{C}$ until analyzed. Lidocaine concentrations were determined by UV spectrophotometry by high performance liquid chromatography (HPLC). A pump (LC-6A) and detector (SPD6A) (Shimadzu, Kyoto, Japan) were used in the HPLC system. We employed the method of analysis introduced by Satoh. ${ }^{18}$ The analytic conditions were as follows: column, Shim-Pack (ODS) $4.6 \times 250 \mathrm{~mm}$ (Shimadzu); mobile phase, $0.05 \mathrm{M} \mathrm{KH}_{2} \mathrm{PO}_{4}, 0.05 \mathrm{M} \mathrm{K}_{2} \mathrm{HPO}_{4}$ /acetonitrile $\mathrm{pH} 4.0(88: 12 \mathrm{vol} / \mathrm{vol})$.

Data obtained were expressed as means \pm SEM. Baseline values, values just before lidocaine infusion $(0 \mathrm{~min}$ values), at five minutes after lidocaine infusion $(5 \mathrm{~min})$ and immediately before convulsions (IBC values) were analyzed to compare MAP and HR within and between groups. Baseline values of MAP and HR were normalized to $100 \%$ in each animal and compared using Kruskal-Wallis test followed by Steel's method of statistical analysis. Blood gas values were compared using two-way analysis of variance followed by Duncan's method. Cumulative convulsant doses and plasma concentrations of lidocaine were compared using one-way analysis of variance followed by Duncan's method, and $P<0.05$ was considered significant.

\section{Results}

Baseline MAP (Group 1: $108 \pm 3$, Group 2: $108 \pm 3$, Group 3: $107 \pm 2 \mathrm{mmHg}$, respectively) was similar for the three groups. The MAP in Groups 2 and 3 was decreased after clonidine pretreatment (Group 2: $93 \pm 1 \%$, Group 3: $90 \pm 1 \%$, respectively) compared with baseline $(P<0.01)$ (Figure). Five minutes after lidocaine infusion, the MAP in Group 3 was increased compared with the 0 min value $(P<0.01)$, but not when compared with baseline. Immediately before the convulsions, the MAP was still increased in Group 3 (111 $\pm 4 \%)$ compared with the baseline and 0 min values $(P<0.01)$. Group 2 also showed an increase of MAP $(P<0.01)$ compared with the 0 min value, but not with baseline.

Baseline HRs (Group 1: $451 \pm$ 7, Group 2: $450 \pm$ 5, Group 3: $448 \pm 3$, respectively) were similar for the three groups. The HRs after clonidine pretreatment were decreased by $6 \pm 2 \%$ in Group $2(P<0.05)$ and 14 $\pm 2 \%$ in Group $3(P<0.01)$, respectively (Figure). Five minutes after the start of the lidocaine infusion, $H R$ was decreased in all groups (Group 1: $83 \pm 2 \%$, Group 2: $77 \pm 2 \%$, Group 3: $69 \pm 1 \%$, respectively) compared with both baseline and 0 min values $(P<0.01)$. Comparisons between groups at five minutes revealed that HRs were lower in Group 2 and Group 3 than in Group $1(P<0.05$ and $P<0.01$, respectively), and in Group 

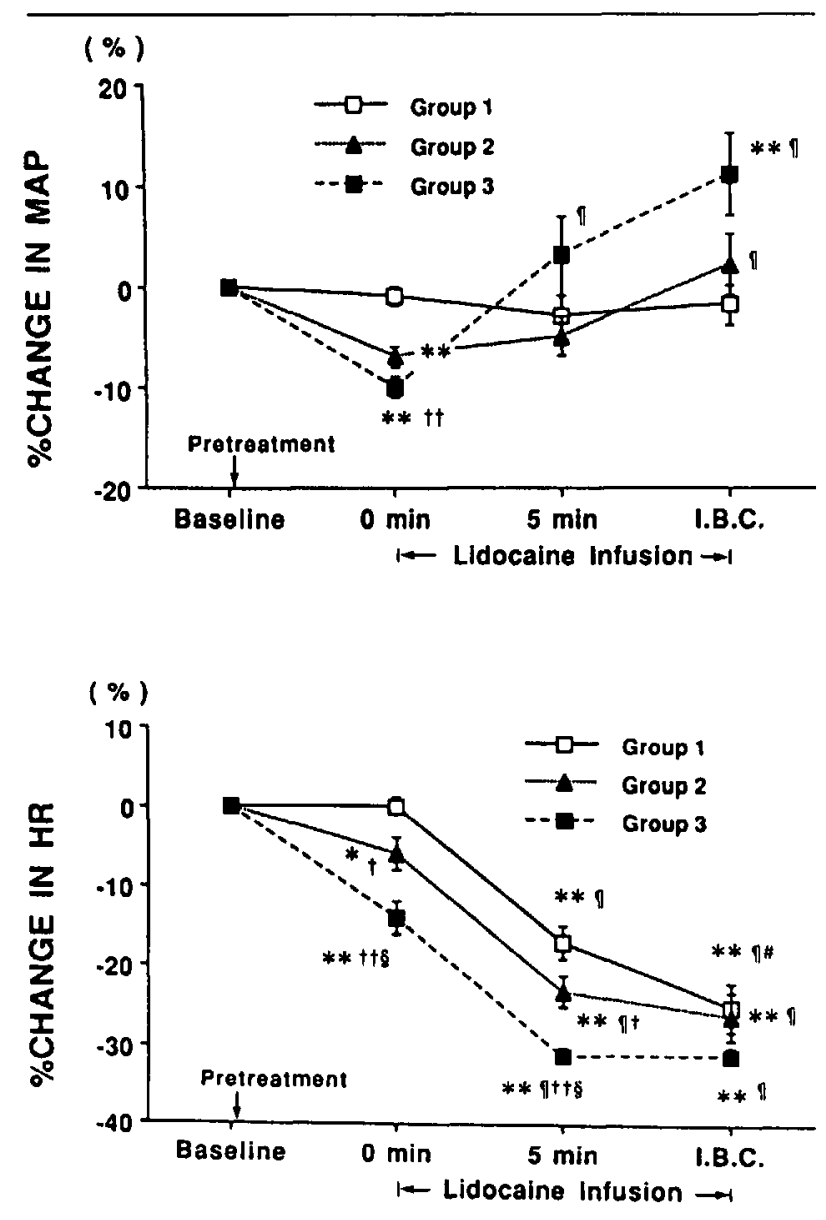

FIGURE Upper figure: percentage changes in mean arterial blood pressure. Lower figure: percentage changes in heart rate. Values are means $\pm \operatorname{SEM}(n=8)$. I.B.C. represents immediately before convulsions. Group 1: control, Group 2: pretreatment with $1 \mu \mathrm{g} \cdot \mathrm{kg}^{-1}$ of $i v$ clonidine, Group 3: pretreatment with $10 \mu \mathrm{g} \cdot \mathrm{kg}^{-1}$ of $i v$ clonidine. ${ }^{* *} P<0.01$ vs baseline, ${ }^{*} P<0.05$ vs baseline, $\uparrow P<0.01$ vs $0 \mathrm{~min}, \# P<0.01$ vs $5 \mathrm{~min}$, $\dagger \uparrow P<0.01$ vs Group $1, \uparrow P<0.05$ vs Group $1, \S P<0.01$ vs Group 2.

3 than in Group $2(P<0.01)$. Immediately before the convulsions, HR was still decreased in all groups (Group 1: $75 \pm 3 \%$, Group 2: $74 \pm 3 \%$, Group 3: $69 \pm 1 \%$, respectively) compared with both baseline and $0 \mathrm{~min}$ values; however, these values were similar for the three groups.

There were no differences among the three groups in blood gas values at $0 \mathrm{~min}$ and at the onset of convulsions (Table I). The $\mathrm{PaO}_{2}$ in Groups 2 and $3, \mathrm{PaCO}_{2}$ in all groups, and $\mathrm{HCO}_{3}$ in Group 3 were increased at the onset of convulsions compared with the values at $0 \mathrm{~min}$. However, these values were still within physiologic ranges.

Pretreatment with clonidine (Groups 2 and 3 ) changed neither cumulative convulsant doses nor plasma concentrations of lidocaine at the onset of convulsions compared with control (Table II).
TABLE I Analysis of blood gases

\begin{tabular}{lccc}
\hline & Group & $0 \mathrm{~min}$ & Convulsions \\
\hline $\mathrm{pHa}$ & 1 & $7.41 \pm 0.01$ & $7.39 \pm 0.01$ \\
& 2 & $7.39 \pm 0.01$ & $7.36 \pm 0.01$ \\
& 3 & $7.39 \pm 0.01$ & $7.40 \pm 0.01$ \\
& & & \\
$\mathrm{PaO}_{2}(\mathrm{mmHg})$ & 1 & $86.7 \pm 1.7$ & $86.9 \pm 1.8$ \\
& 2 & $80.6 \pm 1.8$ & $88.8 \pm 2.1^{*}$ \\
& 3 & $85.1 \pm 2.1$ & $94.4 \pm 4.1^{*}$ \\
$\mathrm{PaCO}_{2}(\mathrm{mmHg})$ & 1 & $35.9 \pm 1.0$ & $40.4 \pm 1.3^{*}$ \\
& 2 & $36.8 \pm 1.3$ & $40.9 \pm 0.7 \dagger$ \\
& 3 & $37.0 \pm 1.0$ & $39.6 \pm 0.9 \dagger$ \\
$\mathrm{HCO}_{3}^{-}\left(\mathrm{meq} \cdot \mathrm{L}^{-1}\right)$ & 1 & $23.2 \pm 0.7$ & $24.5 \pm 0.5$ \\
& 2 & $22.5 \pm 0.5$ & $23.0 \pm 0.6$ \\
& 3 & $22.4 \pm 0.5$ & $24.1 \pm 0.7 \dagger$ \\
\hline
\end{tabular}

Values are means $\pm \mathrm{SEM} ; n=8$.

Group 1: control; Group 2: pretreatment with I $\mu \mathrm{g} \cdot \mathrm{kg}^{-1}$ of $i$ clonidine; Group 3: pretreatment with $10 \mu \mathrm{g} \cdot \mathrm{kg}^{-1}$ of $i v$ clonidine. $* P<0.05$ vs 0 min.

$\dagger P<0.01$ vs $0 \mathrm{~min}$

TABLE II Cumulative convulsant dose and plasma concentration of lidocaine

\begin{tabular}{lll}
\hline & \multicolumn{2}{l}{ Lidocaine } \\
\cline { 2 - 3 } Group & Dose $\left(\mathrm{mg} \cdot \mathrm{kg}^{-1}\right)$ & Concentration $\left(\mu \mathrm{g} \cdot \mathrm{ml}^{-1}\right)$ \\
\hline 1 & $41.8 \pm 2.2$ & $10.5 \pm 0.3$ \\
2 & $43.8 \pm 2.6$ & $10.8 \pm 0.3$ \\
3 & $42.3 \pm 2.0$ & $10.6 \pm 0.3$ \\
\hline
\end{tabular}

Values are means $\pm \mathrm{SEM}, n=8$.

Group 1: control; Group 2: pretreatment with $1 \mu \mathrm{g} \cdot \mathrm{kg}^{-1}$ of $i v$ clonidine; Group 3: pretreatment with $10 \mu \mathrm{g} \cdot \mathrm{kg}^{-1}$ of $\dot{\omega}$ clonidine.

\section{Discussion}

Doses of $1-3 \mu \mathrm{g} \cdot \mathrm{kg}^{-1} \dot{w}$ clonidine are used in clinical practice. $9,19,20$ We chose doses of $1 \mu \mathrm{g} \cdot \mathrm{kg}^{-1}$ and 10 $\mu \mathrm{g} \cdot \mathrm{kg}^{-1} \dot{\boldsymbol{N}}$ clonidine which decreased MAP. Plasma concentrations of clonidine were not measured. The hypotensive effect of clonidine derives from its stimulation of central $\alpha_{2}$ adrenoceptors, resulting in reduction of sympathetic outflow. ${ }^{21,22}$ However, alternatively, at plasma concentrations of $>2 \mathrm{ng} \cdot \mathrm{ml}^{-1}$, clonidine may cause hypertension by stimulating peripheral vascular $\alpha$ adrenoceptors. ${ }^{23}$ This hypertensive phase is often observed immediately after an injection of high-dose clonidine. A hypertensive phase was not observed in our model. After initial reductions following clonidine bolus injections, the MAPs in Group 2 and Group 3 increased with time during lidocaine infusion compared with baseline values, but the reason for this is not clear. Higher concentrations of lidocaine might have suppressed the $\alpha_{2}$ adrenoceptor stimulating effect of clonidine in the CNS, 
which might have unmasked the effect of clonidine on peripheral $\alpha$-adrenoceptors to cause an increase of blood pressure.

Bradycardia occurs following the administration of clonidine ${ }^{24,25}$ due to reduced sympathetic activity, and also to increased parasympathetic tone. ${ }^{26}$ Subconvulsant doses of lidocaine can decrease sympathetic activity and cause bradycardia. ${ }^{27}$ Thus, the slowed HRs in Group 2 and Group 3 at five minutes were considered to be due to the additive effects of clonidine and lidocaine. The reduction in HRs in Groups 2 and 3, however, reached plateaus five minutes after lidocaine infusion and there were no differences among the three groups immediately before convulsions. Our data suggest that the effect of clonidine on blood pressure and HR will become unpredictable as plasma lidocaine concentration is increased.

Several investigators have suggested that central catecholamines play a role in the control of convulsions. ${ }^{28-30}$ Prejunctionally located $\alpha_{2}$-adrenoceptors are known to modulate the release of norepinephrine and there is considerable evidence that norepinephrine may play a role in experimentally induced convulsions. ${ }^{30}$ There have been several reports that clonidine has anticonvulsant or proconvulsant effects, ${ }^{13-17}$ depending on the aetiology of the convulsions or depending on the dose of clonidine administered. An anticonvulsant effect of clonidine was observed in seizures induced by picrotoxin, strychnine, and electric shock in mice and rats, ${ }^{13}$ or D,L-allylglycine in rats. ${ }^{14} \mathrm{~A}$ proconvulsant effect of clonidine was observed in seizures induced by tactile stimulation of quaking mice. ${ }^{15}$ Therefore, it appears that, depending on the aetiology of the seizure, clonidine either facilitates or inhibits the seizure threshold. ${ }^{31}$ However, these studies used large doses of clonidine $\left(50-1000 \mu \mathrm{g} \cdot \mathrm{kg}^{-1}\right)$. We did not examine the effect of clonidine on lidocaine-induced convulsions, at doses much higher than the expected clinical dosage ranges, since our preliminary study showed that $>100 \mu \mathrm{g} \cdot \mathrm{kg}^{-1}$ intraperitoneal clonidine caused prolonged hypertension. Thus, clonidine, in doses of 0.5 $\mathrm{mg} \cdot \mathrm{kg}^{-1}$ or $1.0 \mathrm{mg} \cdot \mathrm{kg}^{-1}$ intraperitoneally administered to rats by Tacke et al. ${ }^{16}$ and Papanicolaou et al. ${ }^{17}$ must have caused severe hypertension, although they did not measure blood pressure. Our results showed the pretreatment with $1 \mu \mathrm{g} \cdot \mathrm{kg}^{-1}$ or $10 \mu \mathrm{g} \cdot \mathrm{kg}^{-1}$ of $i v$ clonidine changed neither the cumulative convulsant doses nor the plasma concentrations of lidocaine at the onset of convulsions compared with control. Judging from the decrease in blood pressure $15 \mathrm{~min}$ after clonidine, the dose of clonidine administered in our experiment caused an $\alpha_{2}$-adrenoceptor effect. Because most convulsions occurred within $25 \mathrm{~min}$ after clonidine injection and the effective duration of clonidine is several hours, ${ }^{19}$ clonidine should still have been effective at the onset of convulsions.
Nishikawa et al. ${ }^{10}$ reported that $5 \mu \mathrm{g} \cdot \mathrm{ml}^{-1}$ or 10 $\mu \mathrm{g} \cdot \mathrm{ml}^{-1}$ clonidine added to lidocaine tended to increase the plasma lidocaine concentrations after $10-15 \mathrm{~min}$ of epidural injection and they speculated that greater plasma lidocaine concentrations might suggest an altered hepatic metabolism of lidocaine by epidural clonidine. Our data showed that $i v$ clonidine did not change the plasma lidocaine concentrations at the onset of convulsions in rats. Although the dose equivalency to the human is not clear, our results suggest that clinical doses of clonidine would not affect the lidocaine seizure threshold in humans.

In conclusion, pretreatment with $1 \mu \mathrm{g} \cdot \mathrm{kg}^{-1}$ or 10 $\mu \mathrm{g} \cdot \mathrm{kg}^{-1}$ of $i v$ clonidine had neither anticonvulsant nor proconvulsant effect on lidocaine-induced convulsions in rats. However, the interactions of clonidine and lidocaine on blood pressure and heart rate should be further investigated.

\section{References}

1 Yaksh TL, Reddy SVR. Studies in the primate on the analgesic effects associated with intrathecal actions of opiates, $\alpha$-adrenergic agonists and baclofen. Anesthesiology 1981; 54: 451-67.

2 Eisenach JC, Dewan DM, Rose JC, Angelo JM. Epidural clonidine produces antinociception, but not hypotension, in sheep. Anesthesiology 1987; 66: 496-501.

3 Gordh $T J r$. Epidural clonidine for treatment of postoperative pain after thoracotomy. A double-blind placebocontrolled study. Acta Anaesthesiol Scand 1988; 32: 702-9.

4 Mendez $R$, Eisenach IC, Kashtan $K$. Epidural clonidine analgesia after Cesarean section. Anesthesiology 1990; 73 : 848-52.

5 Ghignone $M$, Noe $C$, Calvillo $O$, Quintin $L$. Anesthesia for ophthalmic surgery in the elderly: the effects of clonidine on intraocular pressure, perioperative hemodynamics, and anesthetic requirement. Anesthesiology 1988; 68: 707-16.

6 Segal IS, Jarvis DJ, Duncan SR, White PF, Maze M. Clinical efficacy of oral-transdermal clonidine combinations during the perioperative period. Anesthesiology 1991; 74: 220-5.

7 Ghignone M, Quintin L, Duke PC, Kehler CH, Calvillo $O$. Effects of clonidine on narcotic requirements and hemodynamic response during induction of fentanyl anesthesia and endotracheal intubation. Anesthesiology 1986; 64: $36-42$.

8 Ghignone $M$, Calvillo $O$, Quintin L. Anesthesia and hypertension: the effect of clonidine on perioperative hemodynamics and isoflurane requirements. Anesthesiology 1987; 67: 3-10.

9 Bernard J-M, Hommeril J-L, Passuti N, Pinaud M. Postoperative analgesia by intravenous clonidine. Anesthesiology $1991 ; 75:$ 577-82. 
10 Nishikawa T, Dohi S. Clinical evaluation of clonidine added to lidocaine solution for epidural anesthesia. Anesthesiology 1990; 73: 853-9.

11 Gaumann DM, Brunet PC, Jirounek P. Clonidine enhances the effects of lidocaine on $\mathrm{C}$-fiber action potential. Anesth Analg 1992; 74: 719-25.

12 Gaumann D, Forster A, Griessen $M$, Habre W, Poinsot $O$, Santa $D D$. Comparison between clonidine and epinephrine admixture to lidocaine in brachial plexus block. Anesth Analg 1992; 75: 69-74.

13 Kulkarni SK. Actions of clonidine on convulsions and behavior. Arch Int Pharmacodyn Ther 1981; 252: 124-32.

14 Ashton $D$. Wauquier $A$. $\alpha$-noradrenaline modulation of D,L-allylglycine seizures. Eur J Pharmacol 1981; 75: 71-4.

15 Chermat $R$, Lachapelle $F$, Baumann $N$, Simon $P$. Anticonvulsant effect of yohimbine in quaking mice: antagonism by clonidine and prazosine. Life Sci 1979; 25: 1471-6.

16 Tacke $U$, Kolonen $S$. The effect of clonidine and yohimbine on audiogenic seizures (AGS) in rats. Pharmacological Research Communications 1984; 16: 1019-30.

17 Papanicolaou J, Summers RJ, Vajda FJE, Louis WJ. Anticonvulsant effects of clonidine mediated through central $\alpha_{2}$-adrenoceptors. Eur J Pharmacol 1982; 77: 163-6.

18 Satoh $Y$. Pharmacokinetics of lidocaine and monoethylglycinexylide after the intratracheal administration of lidocaine. Masui 1988; 37: 1192-8.

19 Arndts $D$, Doevendans $J$, Kirsten $R$, Heintz $B$. New aspects of the pharmacokinetics and pharmacodynamics of clonidine in man. Eur J Clin Pharmacol 1983; 24: 21-30.

20 Zochowski $R J$, Lada $W$. Intravenous clonidine treatment in acute myocardial infarction (with comparison to a nitroglycerin-treated and control group). J Cardiovasc Pharmacol 1986; 8: S41-45.

21 Farsang C, Ramires-Gonzalez MD, Mucci L, Kunos G. Possible role of an endogenous opiate in the cardiovascular effects of central alpha adrenoceptor stimulation in spontaneously hypertensive rats. J Pharmacol Exp Ther 1980; 214: 203-8.

22 Schmitt H, Schumitt-Jubeau H, Daskalopoulus NTH. Central mechanisms of clonidine. Trends Pharmacol Sci 1979; 1: 71-3.

23 Kobinger $V W$, Walland $A$. Circulation studies with $2-2,6-$ dichlorophenylamino)-2-imidazoline hydrochloride. Arzneimittelforschung 1967; 17: 292-300.

24 Byrd BF III, Collins HW, Primm RK. Risk factors for severe bradycardia during oral clonidine therapy for hypertension. Arch Intern Med 1988; 148: 729-33.

25 Etta $L Y$, Burchell $H$. Severe bradycardia with clonidine (Letter). JAMA 1978; 240: 2047.

26 Kobinger $W$. Pichler I. Localization in the CNS of adrenoceptors which facilitate a cardioinhibitory reflex. NaunynSchmiedebergs Arch Pharmacol 1975; 286: 371-7.
27 Nishikawa K, Fukuda T, Yukioka H, Fujimori M. Effect of intravenous administration of local anesthetics on the renal sympathetic nerve activity during nitrous oxide and nitroux oxide-halothane anesthesia in the cat. Acta Anaesthesiol Scand 1990; 34: 231-6.

28 Kilian $M$, Frey $\boldsymbol{H}$. Central monoamines and convulsive thresholds in mice and rats. Neuropharmacol 1973; 12: 681-92.

29 Jobe $P C$, Stull RE, Geiger PF. The relative significance of norepinephrine, dopamine and 5-hydroxytryptamine in electroshock seizure in the rat. Neuropharmacol 1974; 13 : 961-8.

30 Mason ST, Corcoran ME. Catecholamines and convulsions. Brain Res 1979; 170: 497-507.

31 Lazarova $M$, Samanin $R$. Potentiation by yohimbine of pentylenetetrazol-induced seizures in rats: role of alpha ${ }_{2}$ adrenergic receptors. Pharamcological Research Communications 1983; 15: 419-25. 